\title{
Mielenterveysohjelmat mielenterveystyötä parantamassa
}

Olin ollut viimeistelemässä väitöskirjan yhteenvetoa eräässä Helsingin keskustan kahvilassa, eräänä heinäkuun lopun perjantai-alkuiltana, kun ulos astuessani näin Lönnrotinkadun ja Mannerheimintien risteyksessä suuren määrän ambulansseja. Niin suuren, että siitä saattoi heti päätellä, että jotain vakavaa oli tapahtunut.

Myöhemmin tapahtuma on osoittautunut mielenterveyskysymykseksi. Tapahtumaa koskevat tietoni ovat peräisin tiedotusvälineiltä, enkä halua tässä yhteydessä sanoa tämän enempää: perjantaina 28.7.2017 viisikymmentäyksivuotias mies oli ajanut piittaamattomasti Helsingin keskustassa ja useita ihmistä oli jäänyt alle. Heistä yksi kuoli.

Muutama päivä tapauksen jälkeen otsikkoihin nousi yliajajan omaisten näkemys, jonka mukaan mielenterveyspalveluiden saaminen on nykypäivänä liian vaikeaa. Tämän jälkeen lehdet ja aivan erityisesti niiden yleisönosastot ovat täyttyneet kirjoituksista, joiden keskeinen viesti on ollut, että mielenterveyspalveluiden tarjonta ja saavutettavuus ovat riittämättömiä tämän päivän Suomessa.

Vastaavia keskusteluita on noussut vuosien saatossa säännöllisin väliajoin. Eräänä esimerkkinä mainittakoon Helsingin Auroran sairaalan psykiat- risen päivystyksen yhdistyminen somaattisen puolen päivystykseen. Näille keskusteluille yhteistä on ollut se, että niissä mielenterveyteen erikoistuneita palveluita on pidetty suuressa arvossa.

Valitettavan heinäkuisen tapauksen nostattamassa keskustelussa on Helsingin sanomissa ehdotettu ainakin kahteen otteeseen vastaukseksi kansallisen mielenterveysohjelman perustamista. Se onkin hyvä idea, sillä selvittämättömiä mielenterveyteen ja mielenterveyspalveluihin liittyviä kysymyksiä tuntuu olevan paljon.

\section{MUTTA ONKO TÄLLAINEN OHJELMA JO TOTEUTETTU?}

Väitöstutkimuksessani, jonka suomenkielinen otsikko on: Mielenterveystyötä parantamassa. Suomalaisen mielenterveyspolitiikan perustelut sairaalaboidon vähentämisen aikakaudella olen tarkastellut juuri tällaisia mielenterveysohjelmia viiden viime vuosikymmenen ajalta. Näiden ohjelmien tavoitteena on ollut suunnitella mielenterveyden hoito Suomessa sellaiseksi, että se vastaisi väestössä esiintyvää tarvetta.

Tutkimukseni keskeinen tulos on, että näissä ohjelmissa tullaan kautta vuosikymmenten ehdottaneeksi samoja asioita.

Ohjelmasta toiseen nämä ehdotukset seuraavat toisiaan:
- On vähennettävä psykiatrista sairaalahoitoa,

- On lisättävä mielenterveyden avohoitoa,

- On lisättävä mielenterveyskuntoutujien mahdollisuuksia osallistua työhön,

- On uudelleenmääriteltävä, ketkä ovat sopivia asiantuntijoita mielenterveyteen liittyvissä kysymyksissä ja

- On lisättävä tasa-arvoa mielenterveyskuntoutujien ja muiden kansalaisten välillä.

Nämä tavoitteet toistuvat, ja moni niistä onkin toteutunut.

Psykiatristen sairaalapaikkojen määrä maassamme on tällä hetkellä noin seitsemäsosa siitä, mitä se oli korkeimmillaan, 1970-luvun puolivälissä. Tämän saavutuksen merkitystä kuitenkin vähentää se, että erilaisten mielenterveysongelmaisille suunnattujen asumispalveluiden käyttö on suurta. Näitä palveluita on kritisoitu laitostaviksi, samalla tavalla kuin psykiatrisia sairaaloitakin. Viime aikoina on kiinnitetty huomiota myös siihen, että vankiloissa on paljon henkilöitä, joilla on vakavia mielenterveysongelmia.

Avohoidon tarjonta on lisääntynyt: asiasta on hankalaa saada kattavia vertailukelpoisia lukuja, mutta esimerkiksi Kansaneläkelaitoksen tukeman 
kuntoutuspsykoterapian käyttö on noin viisikymmenkertaistunut 1980-luvun alun jälkeen (mikä on varhaisin saatavilla oleva luku). Vasta 1990-luvulla markkinoille tulleita niin sanottuja kolmannen sukupolven masennuslääkkeitä, serotoniinin takaisinoton estäjiä eli SSRI-lääkkeitä käytti vuonna 2015 lähes puoli miljoonaa suomalaista.

Merkittävä muutos on sekin, että aiemmin psykiatrivaltainen mielenterveystyön järjestelmä on alkanut kuulla palveluiden käyttäjiä, joita on viime vuosina alettu nimittää kokemusasiantuntijoiksi.

Mielenterveyskuntoutujien työssäkäyntimahdollisuuksien edistymisestä sen sijaan on vähemmän merkkejä. Mielenterveysperusteisten työkyvyttömyyseläkkeiden määrä on noussut viime vuosiin saakka ja sitä pidetään edelleen suurena ongelmana.

Myös mielenterveyskuntoutujien tasa-arvotavoitteen täyttyminen näyttää monella tavalla kyseenalaiselta.

Avohoitoa lisättäessä on tarkastelemani ajanjakson alkuvaiheessa ehdotettu kiinnitettävän huomiota erityisesti niihin ryhmiin ja henkilöihin, jotka sitä ennen olivat psykiatrisessa sairaalahoidossa ja joiden katsottiin olevan vaarassa laitostua.

Sittemmin mielenterveystyön kohteeksi on vähitellen yhä vankemmin noussut meidän kaikkien mielenterveys. Samaan aikaan ohjelmista on tähän päivään mennessä vähitellen hävinnyt tarpeen käsite. Tämä tarkoittaa sitä, että ohjelmat eivät sano, että me kaikki tarvitsemme mielenterveyspal- veluita. Mutta, ne eivät myöskään sano, että sairaimmat tai vaikeimmassa asemassa olevat tarvitsisivat niitä.

Tämän muutoksen merkitys tulee esiin historiallisessa vertailussa: esimerkiksi 1980luvulla toteutettu skitsofreniaprojektiksi kutsuttu hanke ehdotti skitsofreniasta kärsiville perheterapian lisäämistä, mutta myös opastusta arkisissa asioissa kuten ruuanlaitossa ja joukkoliikenteen käytössä. Nykypäivänä mielenterveysohjelmat pidättäytyvät fokusoimasta sairauksiin tai antamasta näin tarkkoja tai hyvin resursoituja suosituksia. 1970- ja 1980-luvuilla eräänä keskeisenä tapana lisätä mielenterveysongelmista kärsivien kansalaisten osallistumista työhön esitettiin kuntouttavien suojatyöpaikkojen lisäämistä.

Toistuvien tavoitteiden ohella tarkastelemissani mielenterveysohjelmissa moni asia myös muuttuu. Näistä huomioni kiinnittyy niihin, jotka liittyvät hyvinvointivaltion tai -systeemin ja yksilön tai kansalaisen väliseen suhteeseen. Tutkimuksen kattaman ajanjakson aikana ohjelmissa näkyy asteittainen muutos siinä, mikä mielletään hyvinvointivaltion velvollisuudeksi kansalaisia kohtaan.

Yhdeksänkymmentäluvun puolivälin jälkeen, aikakautena, jota on joskus nimitetty pysyvän niukkuuden aikakaudeksi, ohjelmissa lakataan puhumasta kansalaisista apua, tai ainakaan asiantuntija-apua tarvitsevina. Palkkatyön painotus lisääntyy, ja siitä tulee keskeinen oikeuttamisperuste niin mielenterveysohjelmien huomion kuin tuenkin jakamisessa.
Se, mitä viimeaikaisissa ohjelmissa ei ole suunnitelmissa huomioitu, on palkkatyöpainotuksen aiheuttama kahtiajako. Niin mielenterveyspalveluissa kuin terveys- ja kuntoutuspalveluiden jaossa yleisemminkin, järjestelmä kohtelee eri tavalla niitä kansalaisia, jotka ovat palkkatyössä kuin niitä jotka eivät ole. Viittaan tähän ilmiöön käsitteellä dualisaatio.

Toinen merkittävä yhteiskunnallinen ilmiö, jota näissä tarkastelemissani mielenterveystyön parantamisohjelmissa ei oteta huomioon on mielenterveyden alan laajeneminen. Tarkoitan kompleksia, joka koskee sekä palveluiden tarjontaa, soveltamisalaa, kysyntää että käyttöä. Kutsun tätä ilmiötä nimellä mielenterveystyön ekspansio. Sen johdosta oikeastaan kuka tahansa voi kokea tarvitsevansa mielenterveyspalveluita ja käyttää niitä.

Mielenterveyspalveluita tarjotaan yhteiskunnassamme paljon ja joillekin jopa suhteellisen avokätisesti. Tämä ei kuitenkaan anna vastausta siihen, miten lisääntynyt mielenterveyden avohoito on pystynyt kompensoimaan sairaalapaikkojen vähentymistä. Olisikin tärkeää kysyä, minkä verran ja millaista avohoitoa tarjotaan niille, jotka aiemmin olisivat olleet sairaalahoidossa. Tähän kysymykseen pelkkä avohoidon lisääntyminen ei ole vastaus.

Montaa kehitystä mielenterveystyössä voidaan tänä päivänä pitää onnistuneena: elämänmittainen laitoksiin sulkeminen on mennyttä, avohoitoa on tarjolla, potilaat saavat äänensä kuuluviin ja työelämän uuvuttamien työkykyä voidaan 
tukea. Silti tarkastelemassani aineistossa huomio kiinnittyy siihen, että 2000-luvulla niissä kiinnitetään suhteellisen vähän huomiota työmarkkinoiden ulkopuolella oleviin tai vakavasti sairaiksi ymmärrettyihin kansalaisiin. Näin ollen tarkastelemani mielenterveystyön parantamiseen tähdänneet ohjelmat näyttävät lopulta epäonnistuneen yhdessä toistuvista tavoitteistaan, pyrkimyksessä lisätä tasa-arvoa.
Anna Alanko

VTT, tutkijatohtori,

koordinaattori

Riippuvuuksien, ybteiskunnallisen sääntelyn ja hallinnan tutkimuskeskus (CEACG), Helsingin yliopisto 